\section{EMBRYRIDDLE}

Aeronautical University

SCHOLARLY COMMONS
Journal of Aviation/Aerospace

Education \& Research

Volume 5

Number 2 JAAER Winter 1995

Article 8

Winter 1995

\title{
The Effect of the Course "Women in Aviation" on College Student Attitudes Regarding Women in the Career Field of Aviation
}

Hope Bouvette Thornberg

Patrick R. Mattson

Richard A. Sundheim

Follow this and additional works at: https://commons.erau.edu/jaaer

\section{Scholarly Commons Citation}

Thornberg, H. B., Mattson, P. R., \& Sundheim, R. A. (1995). The Effect of the Course "Women in Aviation" on College Student Attitudes Regarding Women in the Career Field of Aviation. Journal of Aviation/ Aerospace Education \& Research, 5(2). https://doi.org/10.15394/jaaer.1995.1151

This Article is brought to you for free and open access by the Journals at Scholarly Commons. It has been accepted for inclusion in Journal of Aviation/Aerospace Education \& Research by an authorized administrator of Scholarly Commons. For more information, please contact commons@erau.edu. 


\title{
THE EFFECT OF THE COURSE "WOMEN IN AVIATION" ON COLLEGE STUDENT ATTITUDES REGARDING WOMEN IN THE CAREER FIELD OF AVIATION
}

\author{
Hope Bouvette Thornberg, Patrick R. Mattson, and Richard A. Sundheim
}

This study was undertaken to determine whether the course "Women in Aviation" had an effect over the time period of the course on college student attitudes on women in aviation. The survey instrument was developed to examine those attitudes. It consisted of 25 statements that invited responses on a five-point Likert-type attitude scale. The survey was administered pre- and post-course with students asked to code their survey forms with an identification number and gender. Comparisons were made between the mean scores of 64 sets of paired responses to each of the statements on pre- and post-course surveys as well as between the mean scores of 60 sets of gender-related responses to the statements. The study suggested the course had an effect on student attitudes and further suggests that the attitude changes that appeared to occur supported women in aviation. The study also seemed to indicate that differences exist between male and female students in their attitudes on women in aviation-related career fields and that these differences persisted over the time period of the course. Finally, this study suggested that there is less agreement among men than among women in their attitudes on women in aviation-related career fields.

\section{INTRODUCTION}

During the 1990-91 academic year, the Aviation faculty at St. Cloud State University began exploring ways to increase female enrollment in the aviation program. At that time women made up approximately $10.82 \%$ of the 305 students. The first woman had joined the aviation faculty that year and she, along with a male colleague, began the research and development for a new course that would demonstrate the aviation program's commitment to attracting and retaining female students. A lower-division course, "Women in Aviation," was approved by the university as a general education, multi-culture/multi-gender course early in 1991 and was first offered the Winter quarter of 1992, with an enrollment of 50 undergraduate students, approximately two-thirds male and one-third female.

The course, team-taught by a male and a female professor, has been offered six times with similar enrollments and gender distribution. The majority of the students are Aviation majors or pre-majors. The broad goal of the course is to develop in students an awareness of the role of women in aviation from its very beginnings through contemporary times. It is hoped that male students will internalize their newly acquired awareness of the role of women in aviation and emerge from the course with an increased sensitivity to women who choose this career field. Female students should emerge from the course with a sense of pride in the achievements made by women in a non-traditional career field as well as with increased confidence in their own ability to succeed in such a career field.

Mid-term and final examinations, a research paper, and group presentations provide the means of evaluating student attainment of the broad, cognitive goal of the course. The additional course outcomes are more affective than cognitive and their attainment may be dependent on attitude change occurring over the time period of the course. Because these affective outcomes are of particular interest in determining course effectiveness, it was decided to develop a survey instrument that would examine student attitudes on women in aviation at the beginning and at the end of the course (Baldwin, 1988). This structure would provide a means of evaluating student attitude change over the 
time period of the course. Attitude change may be indicative of attainment of affective course outcomes.

\section{PURPOSE OF THE STUDY}

This study was undertaken to determine whether the course "Women in Aviation" had an effect over the time period of the quarter-length course on college student attitudes on women in the career field of aviation.

\section{METHODOLOGY}

R. A. Likert's method of attitude scale construction was used to develop a survey instrument to examine student attitudes on women in aviation (Brown, 1984; Gronlund, 1989). The survey consists of 25 statements that invite responses on a five-point Likert-type scale: (5) strongly agree, (4) agree, (3) neutral, (2) disagree, and (1) strongly disagree. The statements were designed to reflect the various roles of women in the aviation field. The responses elicited were verbal expressions of feelings and opinions held by college students on women in this career field. The survey statements were reviewed by members of the Industry Advisory Board to the Aviation program, including the director of the university's Women's Studies program. The survey was further reviewed by a university non-aviation faculty member who has extensive experience and expertise in survey design. The instrument underwent refinement consistent with recommendations of these individuals and within the parameters of Likert-type attitude scale construction.

The attitude survey was administered to the students at the initial class meeting of the course "Women in Aviation." The survey was re-administered to students at the last regular class meeting. Students were asked to identify their gender and to assign themselves an identifying code number to be placed on the pre-course survey and the post-course survey. The code numbers allowed the data collected to be paired. Only paired data were included in the study. Students were instructed to read the 25 statements and to record their initial response to each statement. They were given approximately 15 minutes to complete the survey.

The sample used in this study were the students enrolled in the "Women in Aviation" course during Spring quarter, 1993, and Winter quarter, 1994. Although 50 students were enrolled in each class, only data from those students who completed and properly coded both the pre-course survey and the post-course survey were included in the study. The sample used for this study was 64 sets of paired student survey data, 39 from the Spring quarter, 1993, class and 25 from the Winter quarter, 1994, class. The low sample from Winter 1994 was due to improper coding of the two surveys by the students. The sample used in the comparisons of male and female responses was limited to those students who indicated gender on their surveys. There were sets of gender-identified, paired student data from 22 women and 38 men.

The Spring 1993 class and the Winter 1994 class were as identical as possible. The tests, texts, videos, assignments, class schedule, guest speakers, and delivery system by the male and female professors were the same.

A t-test was used to compare the mean scores of the responses for each of the 25 statements in the paired preand post-course surveys. A t-test also was used to compare the mean scores of responses made by men and by women to the 25 statements in the two surveys. Finally, a t-test was conducted to compare the mean scores of gender-related responses in the pre- and post-course surveys. In addition, an F-test was used to compare the variance of responses among men and women.

\section{ANALYSIS OF DATA}

Because a large number of t-tests were performed, it is suggested that those tests that have an observed significance level less than .005 should be declared significant. Those tests with an observed significance level between .005 and .01 should be considered as exhibiting a possible trend that is not quite strong enough to be considered significant. Those with an observed significance level between .01 and .05 should bear watching in further studies. If a significance level of .05 is used for all tests and a large number of tests are being performed, the danger exists that several of the differences would be found significant by pure chance rather than by any real differences. Thus the most important findings in this study will be significant at the .005 level. All other significant differences will be somewhat more speculative.

To compare the pre-course mean scores with the post-course mean scores, a paired t-test was performed 
Table 1

Pre-Course vs. Post-Course Attitudes

\begin{tabular}{|c|c|c|}
\hline $\begin{array}{c}\text { Survey } \\
\text { Statement }\end{array}$ & $\begin{array}{c}\text { Pre-course } \\
\text { mean }\end{array}$ & $\begin{array}{c}\text { Post-course } \\
\text { mean }\end{array}$ \\
\hline $2^{* * *}$ & 3.1 & 2.5 \\
\hline $9 * *$ & 3.1 & 3.5 \\
\hline $11^{* *}$ & 3.0 & 2.5 \\
\hline $13^{*}$ & 4.4 & 4.6 \\
\hline $14^{*}$ & 4.2 & 4.5 \\
\hline $20^{* * *}$ & 2.0 & 1.7 \\
\hline
\end{tabular}

$* \mathrm{P}<.05,{ }^{* *} \mathrm{P}<.01,{ }^{* * *} \mathrm{P}<.005$

on the responses to each of the 25 survey statements. The significant differences are shown in Table 1. Statements 2 and 20 were highly significant. Students were neutral (mean of 3.1) before the course when asked if "The role of women in aviation is relatively new as compared to the role of men" (\#2) and disagreed (mean of 2.5) following the course. Students disagreed both before and after the course (means of 2.0 and 1.7 respectively) with the statement that "Women pilots serving in the military reduces military combat readiness" (\#20). Following the course, they felt significantly stronger in their disagreement. Statements 9 and 11 were significant at the .01 level but not at the .005 level. Before the course the students were neutral to both statements (mean of 3.1 and 3.0 respectively). After the course, they agreed (mean of 3.5) that "The bonding that occurs among male military pilots remains with them in civilian aviation and serves as a barrier to women seeking aviation careers" (\#9). Also, after the course they disagreed (mean of 2.5) with the statement that "The contributions of men to aviation are far greater than those of women" (\#11).

To determine whether there was a statistically significant difference between the mean scores of the responses made by men and by women, three different two-sample t-tests for independent groups were performed on each of the 25 survey statements. When the equal variance assumption was met, a pooled t-test was run; otherwise Satterthwaite's approximate t-test was used. When there was a significant difference between men and women with respect to the variance of their responses using an F-test, it was found that the women had the smaller variance and thus were more consistent as a group in their responses than the men.

The first of these three t-tests used the pre-course data; the results are shown in Table 2. Comparisons of the mean scores of male and female responses to statements 6 and 22 were highly significant. Men disagreed (mean of 2.1) and women were neutral (mean of 3.0) to the statement that "Male pilots are uncomfortable accepting direction from female air traffic controllers" (\#6). Although both men and women disagreed (means of 1.8 and 1.3 respectively), women disagreed more strongly to the statement that "More time is required to train women than men in air traffic control

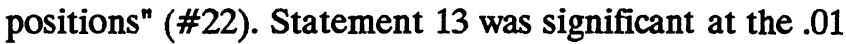
level but not at the .05 level. Although both men and women agreed (means of 4.2 and 4.7 respectively), women agreed more strongly with the statement that "Female flight instructors are as competent as male flight instructors" (\#13).

Table 2

Female vs. Male Attitudes on Pre-Course Survey Statements

\begin{tabular}{|c|c|c|}
\hline $\begin{array}{c}\text { Survey } \\
\text { Statement }\end{array}$ & $\begin{array}{c}\text { Female } \\
\text { Mean }\end{array}$ & $\begin{array}{c}\text { Male } \\
\text { Mean }\end{array}$ \\
\hline $6^{* * *}$ & 3.0 & 2.1 \\
\hline $11^{*}$ & 2.5 & 3.2 \\
\hline $12^{*}$ & 2.9 & 3.4 \\
\hline $13^{* *}$ & 4.7 & 4.2 \\
\hline $17^{*}$ & 1.4 & 1.9 \\
\hline $18^{*}$ & 3.5 & 2.8 \\
\hline $20^{*}$ & 1.7 & 2.2 \\
\hline $22^{* * *}$ & 1.3 & 1.8 \\
\hline
\end{tabular}

${ }^{*} \mathrm{P}<.05,{ }^{* *} \mathrm{P}<.01,{ }^{* * *} \mathrm{P}<.005$ 
Table 3

Female vs. Male Attitudes on Post-Course Survey Statements

\begin{tabular}{|c|c|c|}
\hline $\begin{array}{c}\text { Survey } \\
\text { Statement }\end{array}$ & $\begin{array}{c}\text { Female } \\
\text { Mean }\end{array}$ & $\begin{array}{c}\text { Male } \\
\text { Mean }\end{array}$ \\
\hline $5^{* * *}$ & 1.4 & 2.1 \\
\hline $6^{* * *}$ & 3.3 & 2.1 \\
\hline $11^{* * *}$ & 2.0 & 2.8 \\
\hline $13^{* * *}$ & 4.9 & 4.4 \\
\hline $14^{* * *}$ & 4.9 & 4.3 \\
\hline $17^{* * *}$ & 1.2 & 1.8 \\
\hline $20^{* * *}$ & 1.3 & 1.9 \\
\hline $22^{* * *}$ & 1.2 & 2.0 \\
\hline $25^{*}$ & 2.0 & 2.7 \\
\hline
\end{tabular}

${ }^{*} \mathrm{P}<.05,{ }^{* *} \mathrm{P}<.01,{ }^{* * * \mathrm{P}}<.005$

The second of these three t-tests used the post-course data; the results are given in Table 3. Comparisons of the mean scores of male and female responses to several statements are highly significant at the .005 level. Comparisons of mean scores of responses to statements $6,11,13,17,20$, and 22 were highly significant on the post-course means and at least somewhat significant on the pre-course means. The pre-course results are shown in Table 2 and have been discussed. Either the pre-course attitudes were still in place following the course (\#6) or the course changed both the male and female attitudes by similar amounts (\#11,13,17, 20, and 22). It is interesting to note that most of these differences in male and female attitudes were stronger after the course than before the course. Statements 5 and 14 gave highly significant gender differences post-course but were not significant even at the .05 level in the pre-course data. Women disagreed more strongly than men with the statement "Female physiology contributes to inconsistencies and unpredictability of work performance" (\#5). The pre-course means on this statement were similar (1.5 for women and 2.0 for men) to the post-course means but there were not significant differences and thus did not appear in Table 2 . Women agreed more strongly than men with statement 14 (means 4.9 and 4.3 respectively), both believing that "An air traffic control supervisor's gender is less important than that supervisor's ability to manage people." The pre-course means for this statement were a little less strong (4.1 for women and 4.2 for men) and it appears that female attitudes on this statement were somewhat more affected by the course than male attitudes.

The third t-test compared the mean scores of male and female responses to each of the 25 statements over the time period of the course. This t-test was performed on the differences, the post-course scores minus the pre-course scores. The results are shown in Table 4. There were no significant differences at the .005 or the .01 level and only two (14 and 18) were significant at the .05 level.

Finally, men and women were compared on their variability in their responses. In all cases where the F-test for equality of variances was significant at either the .005 or the .01 level, the men were more variable than the women. For the pre-course data, this variance occurred with statements 3 and 13 and with the post-course data it occurred with statements 13,14 , and 22 . For the post-course minus pre-course differences, the apparent male change in attitude was more variable than the female change in attitude for statements 8,13 , and 19.

\section{CONCLUSION}

This study suggests that the course "Women in Aviation" had an effect over the time period of the quarter-length course on college student attitudes on women in the career field of aviation. The course

Table 4

Female vs. Male Attitudes on Post-Course Survey Statements

\begin{tabular}{|c|c|c|}
\hline $\begin{array}{c}\text { Survey } \\
\text { Statement }\end{array}$ & $\begin{array}{c}\text { Female } \\
\text { Mean }\end{array}$ & $\begin{array}{c}\text { Male } \\
\text { Mean }\end{array}$ \\
\hline $14^{*}$ & 0.77 & 0.05 \\
\hline $18^{*}$ & -0.57 & 0.27 \\
\hline
\end{tabular}

${ }^{*} \mathrm{P}<.05,{ }^{* * P}<.01,{ }^{* * * P}<.005$ 
appeared to have prompted a moderately strong change in overall student response to four of the survey statements and a less strong change in response to two additional statements. These changes suggested positive student attitude change on women in the career field of aviation.

The study also seemed to indicate that differences exist between male and female students in their attitudes on women in aviation careers and that these differences remained over the time period of the course. It further suggested that there is less agreement among men than among women in their attitudes on women in aviation careers.

Although attitude scales are widely used to evaluate affective learning and attitude change, their value is limited by the willingness of individuals to share their feelings, thoughts, and opinions with others. Further, just because an individual appears to hold a particular attitude, there is no guarantee that behavior will be consistent with that attitude (Brown, 1984; Gronlund, 1989). The findings of this study will be useful in identifying in the course "Women in Aviation" some content areas that should receive greater emphasis in an effort to support the affective course outcomes. The findings also will be useful in identifying areas of future research in student attitudes on women in aviation-related career fields.

Further research should include the collection of student data on the number of multi-culture/multi-gender (MGM) courses taken before the course "Women in Aviation." St. Cloud State University students are required to take 12 credits ( 3 courses) of MGM courses. Paired data should be grouped according to number of credits taken and then examined to determine whether the effect of the "Women in Aviation" course on college student attitudes on women in the career field of aviation is altered by the amount of previous MGM coursework taken. Data collection also should include student identification of the major area of study to determine whether attitudes on women in aviation differ between aviation students and non-aviation students.

Hope Bouvette Thornberg earned a Ph.D. from the University of Minnesota and holds various flight certificates and ratings. She is a Professor in the Aviation program at St. Cloud State University, where she teaches pilot ground schools and co-teaches the Women in Aviation class.

Patrick R. Mattson earned an M.S. from Central Michigan University and is a former air traffic controller. He is an Assistant Professor in the Aviation program at St. Cloud State University, where he teaches air transportation, air traffic control, and aviation management classes as well as co-teaching the Women in Aviation class.

Richard Sundheim earned a Ph.D. from Purdue University and is an Associate Professor in the Department of Statistics at St. Cloud State University.

\section{REFERENCES}

Baldwin, C. L. (1988, March). Research choices for measuring outcome of high school groups. Journal for Specialists in Group Work, 3(1), 2-8.

Brown, F. G. (1984). Principles of educational and psychological testing (3rd ed.). New York: Holt, Rinehard and Winston.

Gronlund, N. E. (1989). Measurement and evaluation in teaching (6th ed.). New York: Macmillan. 